\title{
Imperfection of the Contractual Relations in the Regional Agrarian Sector
}

\section{Daria Sergeevna Benz}

\section{Elena Sergeevna Silova}

Chelyabinsk State University Email: sci.publ@gmail.com

\section{Doi:10.5901/mjss.2015.v6n5s2p615}

\section{Abstract}

The article discovers problems of imperfection and an inefficiency of the contractual relations in agrarian sector of Russian regions, which undermine the bases of regional food security. Moreover, in the conditions of sanctions and new economic and political threats agrarian complex development has the biggest priority among economic tasks Russia's facing. Finally, the level of food security is determined by the peculiarities of subjects' behavior in agrarian sector. As for these subjects we mean farmers, manufacturers, merchandisers, consumers and the government. In this article we introduce the evaluation technique of regional food security level. As for two key conditions of food security we consider, first of all, price affordability of key food products and, the second, sufficiency of its consumption. Under developed technique we analysed the food security' condition in Chelyabinsk Region (Russia). In the end of the article we develop a number of the models showing the roots of imperfection of the contractual relations in agrarian sector.

Keywords: agrarian sector, agrarian policy, government regulation of agriculture, food security, contractual relations' efficiency, elasticity of contractual relations' efficiency.

\section{Introduction}

Contractual relations are the dominating form of any economic relations in modern business. The problems of Russian agrarian sector are especially actual nowadays. The last months were marked by the abrupt growth of political and economic risks. The sanctions of European Union and USA put over Russian subjects, led to growth of loan capital's cost. In connection with this sanctions Russia has to keep economic and social stability. In order to withstand the aggressive pressure of international environment, our country, its regions and municipalities, have to achieve a sustainable development of all economic sectors. The agrarian sector is strategically significant for Russian economy. According to the experts, approximately $8,5 \%$ of gross domestic product is produced in this sector, $3,4 \%$ of basic assets is concentrated, more than $11 \%$ of all employee are occupied (Skrynnik, 2010).

There are three objectives of our research:

- to develop the evaluation technique of regional food security level;

- to analyse and estimate the condition of agrarian sector in Chelyabinsk Region;

- to construct a number of models of contractual relations' efficiency.

As for subjects of the contractual relations we mean the following faces: farmers, manufacturers, merchandisers, consumers and the government (Figure 1).

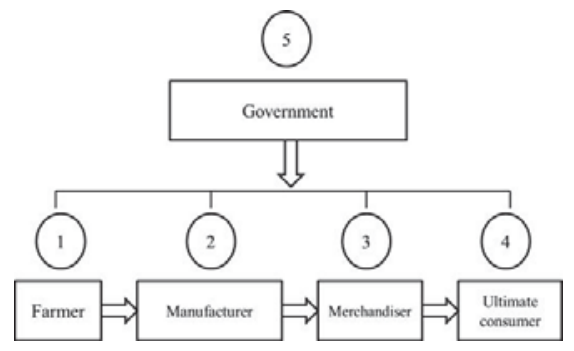

Figure 1. The subjects of the contractual relations in agrarian sector. 
As for the contractual relations in agrarian sector we mean a special sort of the economic relations between, at least, two subjects concerning purchase and sale of foodstuff on the basis of developed institutes' system.

As for essential characteristics of the contractual relations we indicate the following:

- there is an object of property rights transfer;

- there are at least two subjects;

- $\quad$ there is a mechanism of constraint to satisfy an agreement.

We define contractual relations' efficiency in agrarian chain as ability of these relations to satisfy economic interests of its relations' subjects. These relations base on distribution of ultimate agricultural product's price. In other words, maximizing efficiency of the contractual relations implies the determination of optimum price - such price which harmonizes interaction between four subjects mentioned.

Considering the problem of contractual relations' efficiency, we use the method of a dichotomy and divide all contractual relations into perfect and imperfect. The contractual relations in regional agrarian sector will be perfect if maximum level of regional food security is reached.

As criteria of regional food security level we accept implementation of the following two conditions:

- sufficiency of key foodstuff consumption:

- price affordability.

Thus, if two mentioned conditions are reached, we can call the contractual relations in regional agrarian sector perfect or effective ones. If at least one of two mentioned conditions isn't satisfied, the efficiency of the contractual relations along with a condition of food security will be insufficient. And, at last, if none of two conditions is satisfied, we can say about extremely negative level of regional food security.

\section{Research Methodology}

An assessment of contractual relations' quality, first of all, has to provide possibilities of assessment of food security condition. For an assessment of regional food security condition we use two coefficients:

$K_{1}$ - the coefficient of sufficiency of key foodstuff consumption;

$K_{2}-$ the coefficient of price affordability.

The first coefficient $\left(K_{1}\right)$ is the sum of ratios the actual consumption of each product $\left(Q_{1}^{a}\right)$ to standard consumption of corresponding product $\left(Q_{i}^{s}\right)$ :

$$
K_{1}=\sum_{i=1}^{n} \frac{Q_{i}^{a}}{Q_{i}^{s}},
$$

where $Q_{i}^{a}$ - actual consumption of $i$-product,

$Q_{i}^{s}$ - standard consumption of $i$-product,

$n$ - quantity of products in consumer' food basket.

Standards of consumption are established with a glance of regional climatic features and are calculated for ablebodied population. Standards of consumption of key food products are defined by the Concept of the food security of Ural Federal District for the period till 2020 [2], developed within the Doctrine of food security of Russian Federation for the period till 2020 [3]. The recommended standards of consumption are presented in Table 1.

Table 1. Quantities of standard consumption of key food products in Ural Federal District

\begin{tabular}{|c|l|c|}
\hline № & Sorts of food products & The recommended standards of annual consumption, kg per capita \\
\hline 1 & Meat and meat foods & 75 \\
\hline 2 & Milk and dairy foods & 305 \\
\hline 3 & Eggs (pcs.) & 250 \\
\hline 4 & Bread & 105 \\
\hline 5 & Potato & 100 \\
\hline 6 & Vegetable and cucurbitaceous products & 150 \\
\hline
\end{tabular}

The source: the Doctrine of food security of Russian Federation (2010 - 2020). The access: http://www.kremlin. ru/news/6752

For calculation of coefficient $K_{1}$ we add a number of simplifications:

1) as the Concept of food security of Ural Federal District $(2010-2020)$ offers standards only for six food products, we will recognize that all consumer's food basket consists of six products mentioned in Table 1; 
2) let's consider that the quantities of the actual consumption can't exceed the recommended standard, otherwise the buyer consumes excessive quantity of the product that doesn't influence food security in any way.

Based on the first simplification, we transform the Formula (1) as follows:

$K_{1}=\sum_{i=1}^{n} \frac{Q_{i}^{a}}{Q_{i}^{s}}=\frac{Q_{1}^{a}}{Q_{1}^{s}}+\frac{Q_{2}^{a}}{Q_{2}^{s}}+\frac{Q_{3}^{a}}{Q_{3}^{s}}+\frac{Q_{4}^{a}}{Q_{4}^{s}}+\frac{Q_{5}^{a}}{Q_{5}^{s}}+\frac{Q_{6}^{a}}{Q_{6}^{s}}$,

Numeration of products in the Formula (2) corresponds to number of products mentioned in Table 1.

Relying on the second simplification, we come at a conclusion that the coefficient of sufficiency of consumption $K_{1}$ will vary from 0 to 6 .

For calculation of coefficient of price accessibility $K_{2}$ we will use the following formula:

$K_{2}=\frac{\sum_{i=1}^{n} C_{i}^{s}}{A I} \cdot 100 \%$,

where $C_{i}$ - consumer expenses on standard quantity of $i$-product,

Al - weight-average income per capita,

$n$ - quantity of products in consumer' food basket.

The calculation of coefficient $K_{2}$ is based on following simplifications:

1) we will consider not actual expenses, but expenses on standard quantity in coefficient numerator. Otherwise calculation of this coefficient loses sense;

2) the consumer' food basket consists of six products mentioned in Table 1.

Based on mentioned simplification, we transform the Formula (3) as follows:

$K_{2}=\frac{C_{1}^{s}+C_{2}^{s}+C_{3}^{s}+C_{4}^{s}+C_{5}^{s}+C_{6}^{s}}{A I} \cdot 100 \%$,

where $C_{i}$ - consumer expenses on standard quantity of $i$-product according to numeration of products in Table 1

The coefficient $K_{2}$ theoretically can vary from zero to infinity. However, in practice this coefficient has finite value. If the coefficient $K_{2}$ has value below $10 \%$, we consider a situation with regional food security perfect. As acceptable level we'll take range from $10 \%$ to $20 \%$. Let's call an interval from $20 \%$ to $30 \%$ a satisfactory condition of food security. Thus, we'll take value of $30 \%$ for the critical level of coefficient $K_{2}$. If the share of consumer' expenses on food products exceeds $30 \%$, it makes an unsatisfactory condition of regional food security.

The matrix presented in Table 2 allows us to make a final conclusion on the condition of regional food security.

Table 2. Matrix, allowed evaluating the condition of regional food security

\begin{tabular}{|c|l|c|c|c|c|}
\hline \multicolumn{2}{|c|}{} & \multicolumn{4}{c|}{$K_{1}$} \\
\cline { 3 - 6 } & {$[0-3]$} & $(3-4]$ & $(4-5]$ & $(5-6]$ \\
\hline \multirow{3}{*}{$K_{2}$} & Below $10 \%$ & Unsatisfactory & Satisfactory & Acceptable & Perfect \\
\cline { 2 - 6 } & {$[10 \%-20 \%)$} & Unsatisfactory & Satisfactory & Acceptable & Acceptable \\
\cline { 2 - 6 } & {$[20 \%-30 \%]$} & Unsatisfactory & Unsatisfactory & Satisfactory & Satisfactory \\
\cline { 2 - 6 } & Over 30\% & Unsatisfactory & Unsatisfactory & Satisfactory & Satisfactory \\
\hline
\end{tabular}

The Source: Developed by authors.

\section{Main Body. Results.}

In this part of the article we evaluate the condition of food security in Chelyabinsk Region. The quantities of consumption of the main food products per capita are specified in Table 3.

Table 3. The quantities of consumption of the main food products, kg per capita

\begin{tabular}{|c|l|c|c|c|c|c|c|c|c|c|}
\hline \multirow{2}{*}{ № } & \multirow{2}{*}{ Sorts of food products } & \multicolumn{9}{|c|}{ Period } \\
\cline { 3 - 10 } & & 2006 & 2007 & 2008 & 2009 & 2010 & 2011 & 2012 & 2013 & 2014 \\
\hline 1 & Meat and meat foods & 66,3 & 69,5 & 74,5 & 70,5 & 77,0 & 78,1 & 80,5 & 83,4 & 83,6 \\
\hline 2 & Milk and dairy foods & 231,1 & 246,2 & 241,2 & 236,5 & 257,8 & 249,8 & 248,3 & 252,0 & 254,4 \\
\hline 3 & Eggs (pcs.) & 210 & 179 & 173 & 174 & 193 & 187 & 187 & 184 & 185 \\
\hline
\end{tabular}




\begin{tabular}{|l|l|c|c|c|c|c|c|c|c|c|}
\hline 4 & Bread & 96,5 & 95,9 & 94,0 & 87,7 & 89,7 & 88,9 & 86,6 & 84,3 & 85,3 \\
\hline 5 & Potato & 58,5 & 59,2 & 59,7 & 57,0 & 55,7 & 54,3 & 54,5 & 48,7 & 49,9 \\
\hline 6 & Vegetable and cucurbitaceous products & 73,6 & 78,5 & 82,1 & 98,0 & 94,9 & 102,1 & 116,9 & 104,9 & 105,8 \\
\hline
\end{tabular}

The Source: According to selective researches.

To calculate the coefficient $K_{1}$ (Formula 2) we use data from Table 3. The results are shown in Table 4.

Table 4. The coefficient of sufficiency of key foodstuff consumption $\left(K_{1}\right)$

\begin{tabular}{|c|l|c|c|c|c|c|c|c|c|c|}
\hline \multirow{2}{*}{ № } & \multirow{2}{*}{ Sorts of food products } & \multicolumn{9}{|c|}{ Period } \\
\cline { 3 - 10 } & & 2006 & 2007 & 2008 & 2009 & 2010 & 2011 & 2012 & 2013 & 2014 \\
\hline 1 & Meat and meat foods & 0,88 & 0,93 & 0,99 & 0,94 & 1,03 & 1,04 & 1,07 & 1,11 & 1,11 \\
\hline 2 & Milk and dairy foods & 0,76 & 0,81 & 0,79 & 0,78 & 0,85 & 0,82 & 0,81 & 0,83 & 0,83 \\
\hline 3 & Eggs (pcs.) & 0,84 & 0,72 & 0,69 & 0,70 & 0,77 & 0,75 & 0,75 & 0,74 & 0,74 \\
\hline 4 & Bread & 0,92 & 0,91 & 0,90 & 0,84 & 0,85 & 0,85 & 0,82 & 0,80 & 0,81 \\
\hline 5 & Potato & 0,59 & 0,59 & 0,60 & 0,57 & 0,56 & 0,54 & 0,55 & 0,49 & 0,50 \\
\hline 6 & Vegetable and cucurbitaceous products & 0,49 & 0,52 & 0,55 & 0,65 & 0,63 & 0,68 & 0,78 & 0,70 & 0,71 \\
\hline \multicolumn{2}{|l|}{ The coefficient $\left(\boldsymbol{K}_{\mathbf{1}}\right)$} & $\mathbf{4 , 4 8}$ & $\mathbf{4 , 4 8}$ & $\mathbf{4 , 5 2}$ & $\mathbf{4 , 4 7}$ & $\mathbf{4 , 6 6}$ & $\mathbf{4 , 6 4}$ & $\mathbf{4 , 7 1}$ & $\mathbf{4 , 5 5}$ & $\mathbf{4 , 6 0}$ \\
\hline
\end{tabular}

The Source: Evaluated by authors.

Table 4 shows that the coefficient $K_{1}$ has no high volatility in the course of time. It constantly remains in the range from 4 to 5 units that points to a satisfactory condition of food security. However, considering the greatest possible value of coefficient (6 units), it is possible to make a conclusion that it is still far to an excellent condition of regional food security.

For end-to-end assessment we should calculate the coefficient $K_{2}$. For calculation of this coefficient according formula 3 or we should calculate the weight-average income per capita (a coefficient denominator). There is a question of selection: if we calculate the coefficient for employed persons, we will take a salary into account. We'll consider that the population has no other income, except a salary, or they are extremely insignificant. If as selection we take all population of Chelyabinsk Region, we should consider along with employees also unemployed residents.

At first we'll go on the first way. Data for January, 2015 about the average number of workers and their average earnings by types of economic activity are shown in Table 5 .

Table 5. Data about the average number of workers and their average earnings by types of economic activity

\begin{tabular}{|c|l|c|c|}
\hline$№$ & The contingent of workers by types of economic activity & $\begin{array}{c}\text { The average } \\
\text { numbers of workers }\end{array}$ & $\begin{array}{c}\text { The average } \\
\text { earnings, rubles }\end{array}$ \\
\hline 1 & Agriculture, hunting and forestry & 29611 & 18242 \\
\hline 2 & Fishery, fish breeding & 344 & 16795 \\
\hline 3 & Mining operations & 19942 & 29541 \\
\hline 4 & Manufacturing industry & 311474 & 28964 \\
\hline 5 & $\begin{array}{l}\text { Power generation and electrical energy distribution. Production and distribution of gas } \\
\text { and water }\end{array}$ & 41364 & 33400 \\
\hline 6 & Building & 49858 & 27741 \\
\hline 7 & $\begin{array}{l}\text { Wholesale and retail trade; repair of vehicles, motorcycles, household products and } \\
\text { subjects of private use }\end{array}$ & 111633 & 26340 \\
\hline 8 & Hotels and restaurants & 14220 & 20669 \\
\hline 9 & Transport and communication & 83723 & 29011 \\
\hline 10 & Financial activities & 21309 & 35755 \\
\hline 11 & Operations with real estate, rent and rendering of services & 92031 & 30983 \\
\hline 12 & Public administration and ensuring military safety, social insurance & 76343 & 30039 \\
\hline 13 & Education & 130484 & 19500 \\
\hline 14 & Health care and providing social services & 101845 & 22806 \\
\hline 15 & Providing other municipal, social and personal services & 34300 & 26007 \\
\hline & ИTOГO: & 1118481 & \\
\hline
\end{tabular}

The Source: According to website http://chelstat.gks.ru. 
After calculating the weight-average income per capita based of data in Table 5, we received value of 27045,77 rubles. To calculate the numerator of coefficient $K_{2}$ (Formula 4) we should estimate the level of prices for each food product. The average prices of six key food products are shown in Table 6.

Table 6. Food prices in Chelyabinsk region (March, 2015).

\begin{tabular}{|c|l|c|}
\hline № & Sorts of food products & Prices, rubles per kilo \\
\hline 1 & Meat and meat foods & 298 \\
\hline 2 & Milk and dairy foods & 46,7 \\
\hline 3 & Eggs (per 10 pcs.) & 61,9 \\
\hline 4 & Bread & 53,2 \\
\hline 5 & Potato & 30,9 \\
\hline 6 & Vegetable and cucurbitaceous products & 37,2 \\
\hline
\end{tabular}

The Source: According to website http://chelstat.gks.ru.

Let's estimate the annual cost of a consumer basket from six specified products based on standard quantities of consumption:

$$
C_{1-6}^{s}=C_{1}^{s}+C_{2}^{s}+C_{3}^{s}+C_{4}^{s}+C_{5}^{s}+C_{6}^{s}=298 \cdot 75+46,7 \cdot 305+61,9 \cdot 250+53,2 \cdot 105+30,9 \cdot 100+37,2 \cdot 150
$$

\section{$=52397$ rubles .}

In calculation of monthly expenses this sum will be at the level of 4366,41 rubles.

Thus, calculation of coefficient $K_{2}$ will lead the following result:

$$
K_{2}=\frac{C_{1}^{s}+C_{2}^{s}+C_{3}^{s}+C_{4}^{s}+C_{5}^{s}+C_{6}^{s}}{A I} \cdot 100 \%=\frac{4366,41}{27045,77} \cdot 100 \%=16,14 \% \text {. }
$$

If in the denominator we consider not earnings of employed persons, but the average income per capita of all inhabitants of Chelyabinsk region, calculation coefficient $K_{2}$ will be following:

$$
K_{2}=\frac{C_{1}^{s}+C_{2}^{s}+C_{3}^{s}+C_{4}^{s}+C_{5}^{s}+C_{6}^{s}}{A I} \cdot 100 \%=\frac{4366,41}{19727,9} \cdot 100 \%=22,13 \% .
$$

For summing up we use the matrix represented in Table 2. The results of calculation coefficient $K_{2}$ over the working persons (1) and overall population of Chelyabinsk Region (2) are shown in Table 7.

Table 7. The results of an assessment of food security' condition in Chelyabinsk Region

\begin{tabular}{|c|l|l|l|l|l|}
\hline \multicolumn{2}{|c|}{} & \multicolumn{4}{|c|}{$K_{1}$} \\
\cline { 2 - 6 } & {$[0-3]$} & $(3-4]$ & $(4-5]$ & $(5-6]$ \\
\hline \multirow{3}{*}{$K_{2}$} & Below 10\% & & & & \\
\cline { 2 - 6 } & {$[10 \%-20 \%)$} & & & Acceptable (1) & \\
\cline { 2 - 6 } & {$[20 \%-30 \%]$} & & & Satisfactory (2) & \\
\cline { 2 - 6 } & Over 30\% & & & & \\
\hline
\end{tabular}

Thus, we can make a conclusion about acceptable or satisfactory condition of food security in Chelyabinsk region.

Today the problem of contractual relations' efficiency in agrarian chain (figure 2 ) is actually reduced to the analysis of efficiency of interaction among four subjects: farmers (1), manufacturers (2), merchandisers (3) and the ultimate consumer (4). 


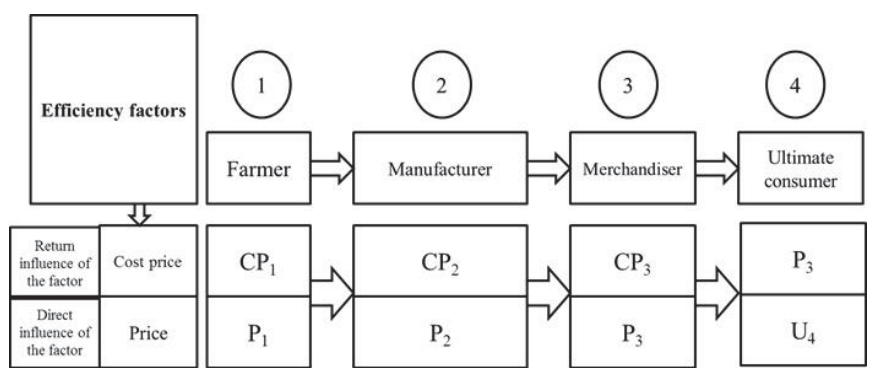

Figure 2. Contract interactions between subjects of an agrarian chain

Let's consider that the purpose function of the first three subjects is maximizing selling price $\left(P_{1}, P_{2}, P_{3}\right)$, and the purpose function of the consumer is maximizing the utility $\left(U_{3}\right)$ from a product.

On Figure 2 we can see the factors of contractual relations' efficiency: for subjects $1-3$ selling prices $\left(P_{1}, P_{2}, P_{3}\right)$ are the factors of efficiency growth, and their expenses $\left(S_{1}, S_{2}, S_{3}\right)$ are the factors of efficiency decrease. For the consumer there is another situation: the higher price of a product $\left(\mathrm{P}_{3}\right)$, the lower contractual efficiency for consumer, as his utility $\left(\mathrm{U}_{3}\right)$ decreases.

Let's suppose that each of three subjects (the farmer, the manufacturer, the merchandiser) has his own function of contractual relations' efficiency $(E)$ showing dependence on selling price $(P)$ :

$$
E_{i}=f\left(P_{i}\right) \text {, }
$$

where $E_{i}$ - contractual relations' efficiency for $i$-subject,

$P_{i}$ - release price for $i$-subject,

$i-1,2,3,4$.

At first we construct functions of contractual relations efficiency for the first three subjects of an agrarian chain. Taking into attention the positive dependence of contractual relations efficiency on the price the general view of function will look like:

$$
E_{i}=k_{i} \cdot P_{i},
$$

where $k_{i}$ - the price elasticity coefficient of contractual relations efficiency for $i$-person.

The price elasticity of contractual relations efficiency for $i$-person for three subjects researched firmly depends on cost price growth rate of cost price $\left(\Delta S_{i}\right)$ :

$$
k_{i}=k_{i}^{\prime} \cdot \frac{1}{S_{i}},
$$

where $S_{i}-$ level of cost price for $i$-person.

Graphically dependence of contractual relations efficiency of subjects $1-3$ of selling price is reflected in Figure 3 .

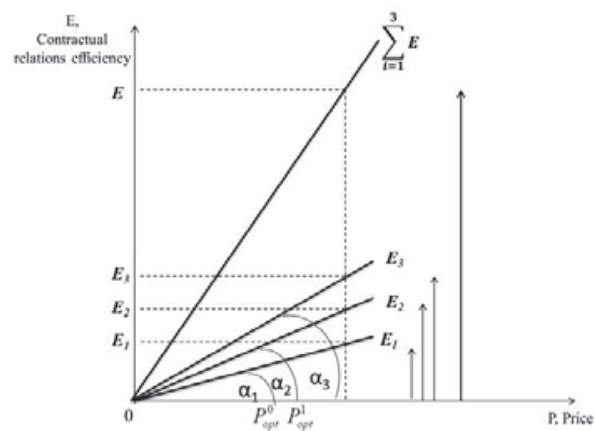

Figure 3. The curve of contractual relations efficiency for farmers $\left(E_{1}\right)$, manufactures $\left(E_{2}\right)$, merchandisers $\left(E_{3}\right)$, total efficiency $(E)$, 
The gradient angles $\alpha 1, \alpha 2, \alpha 3$, demonstrate the three subjects' price elasticity of contractual relations efficiency:

$$
\operatorname{tg} \alpha=\frac{\Delta E}{\Delta P}
$$

The factor of costs is the key for price elasticity of contractual relations efficiency.

Let's summarize curves of contractual relations efficiency $(E 1, E 2, E 3)$ vertically. In that way total efficiency will be reflected by curve $E$.

The ultimate consumer also has his own efficiency curve of contract relations efficiency $\left(E_{4}\right)$. Peculiarity of this curve is its negative slope (Figure 4). The lower price of consumption the higher his satisfaction. This idea is also reflected by the curve of contractual relations efficiency $\left(E_{4}\right)$ :

$$
E_{4}=-k \cdot P+b
$$

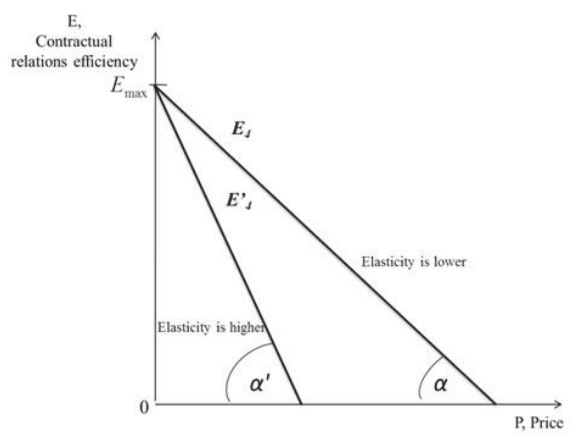

Figure 4. The curve of contractual relations efficiency for ultimate consumer $\left(E_{4}\right)$

Similar to the situation represented in Figure 2, gradient angles $\alpha$, $\alpha$ ' show elasticity of contractual relations efficiency for the ultimate consumer:

$$
\operatorname{tg} \alpha=\frac{\Delta E}{\Delta P}
$$

The key factor of price elasticity of contractual relations efficiency for consumer is his utility. Product utility reflects importance of goods for consumer. The researched elasticity is derivative from elasticity of demand for food products.

Let's determine a total curve of contractual relations efficiency of all subjects researched (TE). The total curve can be received by addition of two curves $\left(\sum E_{1-3}\right.$ and $\left.E_{4}\right)$. The Figure 5 shows the total curve of contractual relations efficiency (TE).

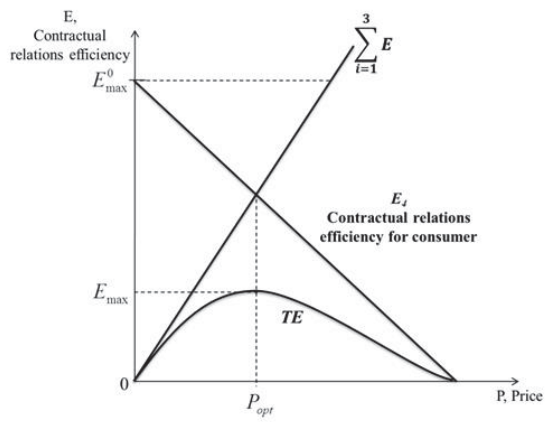

Figure 5. The total curve (TE) of contractual relations efficiency for all the subjects of contractual relations

If we take into account elasticity of contractual relations efficiency, we can displace the curve $E_{1-3,}$ and then we can 
construct a new curve of total efficiency $T E_{1}$ (Figure 6).

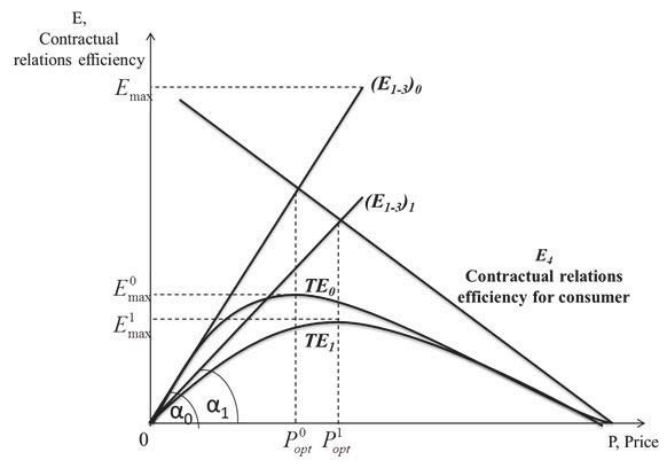

Figure 6. Shift of total curve of contractual relations efficiency (TE) as a result of any factor's impact on elasticity of the curve $E_{1-3}$

If we take into account that elasticity of contractual relations efficiency for consumer changes, this factor displaces curve $E_{4}$. The Figure 7 shows new total curve of contractual relations efficiency $T E_{2}$.

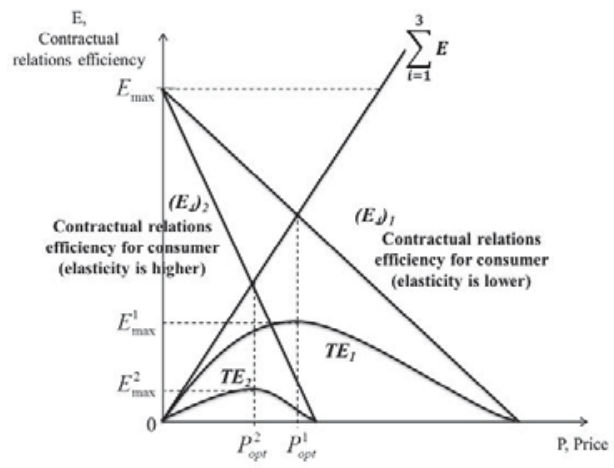

Figure 7. Shift of total curve of contractual relations efficiency (TE) as a result of any factor's impact on elasticity of the curve $E_{4}$.

\section{Discussions}

The problem of the contractual relations is the new one in economic science. The theory of contracts gained the distribution within new institutional school. However, scientists paid attention to the problem of food security a long time ago. Still physiocrats, led by F. Quesnay, assume that the main source of wealth is agriculture. Work in this sphere of agriculture they called productive unlike any other "sterile" work.

The surplus product is created directly by work of farmers and provides welfare for all society, thus, the central sector of any economy is agrarian(Quesnay, 1972). Malthus, T was the first economist who pointed at danger of overpopulation in the Earth taking into account the law of the decreasing productiveness of soil (Malthus, 1820). He pointed at necessity of marriage regulations and birth rate regulation.

As for present time, the end of the XX century was marked by unprecedented growth of planet population, especially in developing countries that caused numerous energy crises and environmental problems.

Conway, G. and Barber, E. define food security as the guaranteed access for all inhabitants to food products 
enough for healthy and active life at any time. And, according to some researchers, the major factor limiting this access is inaccessibility of energy, especially it concerns developing countries. The authors, mentioned above, see the solution in the state policy directed to support agro-industrial complex, fight against poverty and birth rate regulation (Conway, Barber , 1990)

According to Gorbacheva, A. and Kupchenko, A, the food security can be characterized as ability of a country to produce enough of food. Thus, food has to be of satisfactory qualitaty and safe for life and health of the population. The government has to pay more attention to low-income population (Gorbacheva A.A., Kupchenko A.Ju, , 2013). These authors mark out the following components of food security: 1) physical availability of food; 2) economic availability of food; 3) safety and quality of the food.

When Mikhaylushkin, P and Barannikova, A determine food security they point at negative influence of external factors. Even in the conditions of political and economic risks the government has to ensure food security (Mihajlushkin P.V., Barannikov A.A, 2013)].

As for Russian scientists, nobody researches the contractual relations efficiency in agrarian sector. The new institutional theory of contracts becomes widespread in the 1970's. For example, Macneil, I. became the first who gave classification of contracts. He determined contracts as mini-societies with the extensive range of norms which aren't limited by those, from which are directly connected with the act of an exchange" (Campbell D, 2004) Macneil's classification marks off the contractual relations on classical, neoclassical and relational. Discrecity, comprehensiveness of agreements and transparency of all future circumstances are characteristics of the classical contract. As for classical contract the formal clauses come out on top. As usually, classical contract is short-term contract. Long-term contracts are characterized by uncertainty. Such contracts are not transparent. Macneil, I. called such contracts neoclassical. Neoclassical contracts are connected with incompleteness of any agreement.

Williamson, $\mathrm{O}$. constructed types of management of the contractual relations and considered questions of opportunism as well as economy of transactional expenses (Williamson O, 1979).

The special approach of Hodgson, G. to contractual relations is following: he connects them with transfer of property rights, and not just with a bipartite transfer of goods, services or money between agents (Hodgson G, 1988).

Jensen, M. and Meckling, W. focused attention on such factors of contractual relations efficiency as asymmetry of information and behavioral opportunism (Jensen, 1976). These factors also result in incompleteness of contract spoken by Hart, O. (Hart., Moore, 1988)

As for Russian scientists Auzan, A., Bendukidze, K., Benz, D., Kozlova, E., Kudryashova, E., Kuzminov, Y., Oleynik, A., Popov, E., Silova, E., Tambovtsev, V., Shastitko, A. and Yudkevich, M. research problems of contractual relations efficiency. For example, Benz, D., Kozlova, E., Silova, E. show interconnection between opportunism, quality of corporate institutes and imperfection of contractual relations (Benz, D.S., E.V. Kozlova and E.S. Silova, 2014)

In this article we touch upon a question of contractual relations imperfection in agrarian sector. This article shows our attempt to unite new institutional approach to the contractual relations imperfection with a problem of regional food security.

\section{Conclusion}

Today, one of the most actual problems of Russian economy is the problem of food security. Among key problems we can find the following:

- the advancing growth rate of food prices in comparison with growth rate of the population's income leads to growth of share of consumer's expenses on products in their total income;

- $\quad$ poor quality of some food products influences health and life expectancy of population;

- low efficiency of some agricultural enterprises, including insufficient financial stability, low labor productivity, lack of investments, technological lag.

The key reason of contractual relations imperfection in Russian agrarian is low competition among landowners. In view of the import embargo on the food from abroad Russian agro-industrial companies and the merchandisers understand essential decrease in the competition today. Therefore, absence of stimuli to expand quantities of production and to rise quality level reduces all economic efficiency. Absence of access for companies to the cheap credits for expansion of its production plays a negative role for all agrarian sector.

Summing up the results, we can point at the key problem of Russian agrarian policy. There is lack of agreement between participants of the agricultural market. Notably, consumers have to buy the extremely expensive product while the farmer, being the first subject in agrarian chain, sometimes realizes the production even at a loss. That's why we can see inefficient redistribution which leads to low contractual relations efficiency. The underdevelopment of institutional 
forms of interaction between subjects mentioned dictates necessity of the government's intervention. The constructed graphic models of contractual relations efficiency will help to make detailed research in the field of development of the mechanism of the government support of agriculture.

\section{Thanks}

This article is prepared within Grant Prezident by MK-6017.2015.6. We express gratitude to the Russian President V. Putin for his trust and Grant's allocation for the research of the problem concern inefficiency of contractual relations in Russian agrarian sector. Besides, we express special gratitude to the Director of Institute of economy of branches, business and administration (Chelyabinsk State University), the Doctor of Economics, professor V. Barkhatov for the help in Grant Prezident's receiving and the constant help in our scientific researches.

\section{References}

Benz, D.S., E.V. Kozlova and E.S. Silova. Opportunism and efficiency of contractual relations in Russian corporations. International Conference on Innovation, Technology transfer and Education. February 3-5, 2014, Prague, Czech Republic CBU International Conference Proceedings 2014, Vol.2, pp.75 - 82. Date Views 08/04/2015 ojs.journals.cz/index.php/CBUConference2013/issue/ current

Campbell D, . Ian Macneil and The Relation Theory of Contract. 2004. Date Views 08/04/2015 www.lib.kobe-u.ac.jp/repository/801000 23.pdf

Doktrina prodovol'stvennoj bezopasnosti Rossijskoj Federacii na period do 2020g. www.kremlin.ru/news/6752

Gorbacheva A.A., Kupchenko A.Ju. Protivorechija upravlenija v obespechenii prodovol'stvennoj bezopasnosti Rossii.

Hart O. S., Moore J. H. Incomplete Contracts and Renegotiation // Econometrica. - 1988. July. — Vol. 56, No. 4.

Hodgson G, Economics and Institutions: A Manifesto for a Modern Institutional Economics (Polity Press, Cambridge, and University of Pennsylvania Press, Philadelphia, 1988). ISBN 0-7456-0277-0.

Jensen M, Theory of the Firm: Managerial behavior, agency costs and ownership structure», with W. Meckling, 1976

Koncepcija prodovol'stvennoj bezopasnosti Ural'skogo Federal'nogo okruga na period do 2020g. www.special.uralfo.ru/prodovolst bez.html

Malthus, T. The Principles of Political Economy Considered with a View to Their Practical Applications. London: John Murray. 1820.

Mihajlushkin P.V., Barannikov A.A. Jelementy, komponenty i kriterii obespechenija prodovol'stvennoj bezopasnosti strany // nauchnyj zhurnal KubGAU 2013. №92 (08). ej.kubagro.ru/2013/08/pdf/06.pdf

Quesnay, F. Tableau économique. 3d ed. Reprint. Edited by M. Kuczynski and R. Meek. London: Macmillan, 1972.

Skrynnik, E. Prodovol'stvennaja bezopasnost' - vazhnejshaja sostavljajushhaja sistemy nacional'noj bezopasnosti Rossii [Tekst] / E. Skrynnik // APK: jekonomika, upravlenie. - 2010. - №01-.S.03-12. elibrary.ru

Williamson O, . Transaction Cost Economics: The Governance of Contractual Relations // Journal of Law and Economics, October 1979, 22, 233-261.

www.ivdon.ru/uploads/article/pdf/IVD_27_Gorbacheva.pdf_2334.pdf

Conway, G., Barber E. After the Green Revolution Sustainable Agriculture for Development London, 1990. - P.60-62. Date Views 08/04/2015 pdf.usaid.gov 